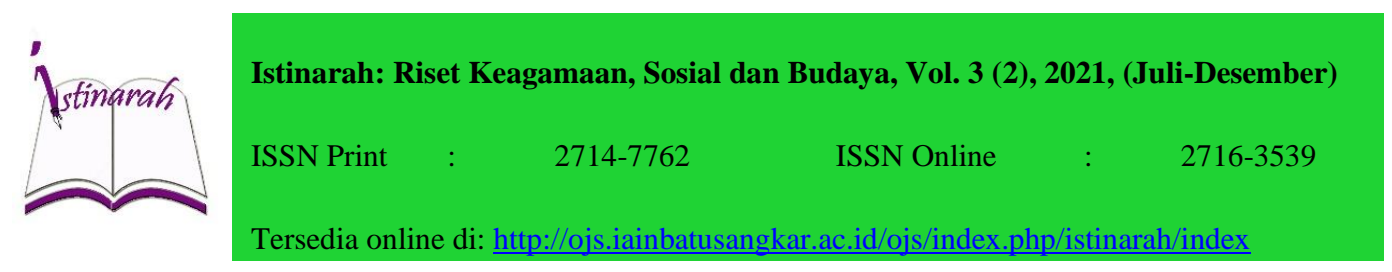

\title{
Strategi Komunikasi dalam Meningkatkan Motivasi Kerja Pegawai di Masa Pandemi Covid-19
}

\author{
Refika Mastanora *) \\ Institut Agama Islam Negeri \\ Batusangkar, Sumatera Barat, \\ Indonesia \\ E-mail: \\ refikamastanora@iainbatusangkar.ac.id
}

\section{Melda Deswita}

Institut Agama Islam Negeri

Batusangkar, Sumatera Barat,

Indonesia

E-mail: meldadeswita37@gmail.com

\begin{abstract}
This paper discusses internal and external factors in increasing employee work motivation at the five people sub-district office during the Covid-19 pandemic. The type of research that researchers use is a type of research that is descriptive field research with a qualitative approach. The data collection technique used in this research is to use observation, interview and documentation techniques. The data analysis technique that the author uses in this study is in the form of data reduction, data presentation and conclusions or verification. The results of the research that the authors get are that the Communication Strategy in increasing Employee Work Motivation at the Lima Kaum Sub-District Office in the Covid-19 Pandemic Period is by monitoring and evaluating, holding meetings with employees at least once a month, establishing good relationships with employees, and completing needs. employees at work.
\end{abstract}

Abstrak: Tulisan ini membahas terkait faktor internal dan eksternal dalam meningkatkan Motivasi Kerja Pegawai di Kantor Camat Lima Kaum di masa Pandemi Covid-19. Jenis penelitian yang peneliti gunakan yaitu field research yang bersifat deskriptif dengan pendekatan kualitatif. Teknik pengumpulan data yang dipakai dalam penelitian ini adalah menggunakan teknik observasi, wawancara dan dokumentasi. Teknik analisis data yang penulis gunakan dalam penelitian ini berupa reduksi data, penyajian data dan kesimpulan atau verifikasi. Hasil penelitian yang penulis dapatkan bahwa Strategi Komunikasi dalam Meningkatkan Motivasi Kerja Pegawai di Kantor Camat Lima Kaum di Masa Pandemi Covid-19 adalah dengan melakukan monitoring dan evaluasi, melakukan pertemuan dengan karyawan minimal satu kali sebulan, menjalin hubungan yang baik dengan karyawan, dan melengkapi kebutuhan operasional karyawan dalam bekerja.

*) Coresponding Author

Kata Kunci: Strategi, Komunikasi, Motivasi, Kerja

\section{PENDAHULUAN}

Era globalisasi saat ini setiap organisasi atau perusahaan yang berbentuk swasta maupun pemerintah, tentunya memiliki tujuan baik itu jangka pendek maupun jangka panjang yang hendak dicapai melalui aktivitas yang dilakukannya. Agar tujuan yang telah ditetapkan tercapai maka diperlukan perencanaan dan pengelolaan sumber daya manusia sebaik-baiknya. 
Istilah sumber daya manusia merujuk pada individu-individu yang ada dalam organisasi yang saling bekerja sama untuk mewujudkan tujuan organisasi. Organisasi atau instansi pemerintahan, komunikasi memiliki peran penting, karena tanpa adanya komunikasi kegiatan tidak berjalan lancar. Komunikasi dalam suatu organisasi dapat mengetahui kepribadian masing-masing baik antara pimpinan maupun pegawai dimana memiliki persepsi dan kebutuhan yang berbeda-beda, oleh sebab itu komunikasi merupakan bagian yang penting dalam suatu organisasi baik dari pimpinan ke bawahan maupun bawahan ke pimpinan serta sesama anggota dalam organisasi.

Pemimpin merupakan orang yang mempunyai kemampuan untuk mempengaruhi sekelompok orang dalam usaha mencapai tujuan organisasi dan mengarahkan para pegawai untuk mencapai tujuannya yang telah disepakati bersama. Suatu instansi dapat mencapai tujuannya jika orang-orang yang berada di dalam instansi tersebut dapat bekerja sama dengan baik untuk mencapai tujuannya, oleh karena itu peran pemimpin sangat berarti dalam mendukung tercapainnya tujuan tersebut. Pada umumnya pemimpin harus mampu memberikan contoh pelayanan yang baik kepada bawahannya, agar para pegawainya termotivasi untuk mengerjakan seperti apa yang dikerjakan oleh pimpinannya, jadi peran seorang pemimpin tidak lepas dari tanggung jawab yang begitu besar terhadap motivasi bawahnnya untuk bekerja semaksimal mungkin sesuai yang diharapkan oleh masyarakat (Astuti, 2019: 25).
Komunikasi pimpinan dapat menciptakan motivasi kerja yang baik bagi bawahan. Komunikasi merupakan suatu aktivitas dasar manusia, dengan adanya komunikasi manusia dapat saling berhubungan antara yang satu dengan yang lain baik dalam kehidupan sehari-hari di dalam rumah tangga, pekerjaan, di pasar, di dalam lingkungan masyarakat maupun dimana manusia itu berada. Menurut Ruliana (2014: 148), komunikasi dapat mempengaruhi kinerja yang dihasilkan seorang karyawan. Komunikasi yang baik dari seorang karyawan membuatnya mampu berinteraksi dalam berkomunikasi baik secara horizontal yaitu dengan rekan sekerja maupun secara vertikal yaitu dengan atasannya. Hal ini dapat dijadikan sebagai alat bagi karyawan tersebut untuk meningkatkan kualitas pekerjaan yang dimiliki karyawan tersebut. Segala sesuatu yang dikomunikasikan dengan baik akan menghasilkan kondisi yang baik.

Strategi yang digunakan dalam meningkatkan motivasi kerja pagawai merupakan hal yang penting harus dilakukan. Strategi menurut Kamus Ilmiah Populer merupakan ilmu siasat perang, muslihat untuk mencapai tujuan (Novia, 2016: 443). Strategi adalah pendekatan secara keseluruhan yang berkaitan dengan pelaksanaan gagasan, perencanaan, dan eksekusi sebuah aktivitas dalam kurun waktu tertentu, dengan adanya strategi komunikasi organisasi pimpinan inilah dapat dilihat pegawai yang memiliki motivasi dan pegawai yang tidak memiliki motivasi dalam bekerja. Apabila dalam strategi komunikasi organisasi terjadi kesalahan dalam pemberian motivasi maka akan terjadi 
problem baru, maka dari itu perlu adanya perencanaan oleh pimpinan guna memberi motivasi kerja kepada pegawai (Astuti, 2019: 23-24).

Dunia sedang dihebohkan dengan munculnya pandemi Corona Virus Disaese (Covid-19), yang membawa dampak signifikan keperubahan dunia. Mulai dari aspek ekonomi, sosial, hingga kehidupan sehari-hari, hampir tak ada yang bisa berkelit dari kemunculan Covid-19 ini, tidak terkecuali terhadap pelayanan publik. Sejak di umumkannya kasus positif covid-19 di Indonesia lalu melalui akun resmi pemerintah dalam penanganan Covid-19 https://covid19.go.id/ diakses tanggal 3 Mei 2021, pemerintah meningkatkan langkah-langkah dalam menangani pandemi global dari Covid19 dan juga berbagai kebijakan telah dikeluarkan oleh pemerintah pusat dan daerah. Mulai dari membatasi hubungan sosial (social distancing), menghimbau untuk bekerja dirumah (work from home) bagi sebagian besar Aparatur Sipil Negara (ASN), membatasi kegiatan beribadah di Mesjid/ Mushola, dan meminta masyarakat untuk tetap di rumah serta mengurangi aktivitas ekonomi di luar rumah.

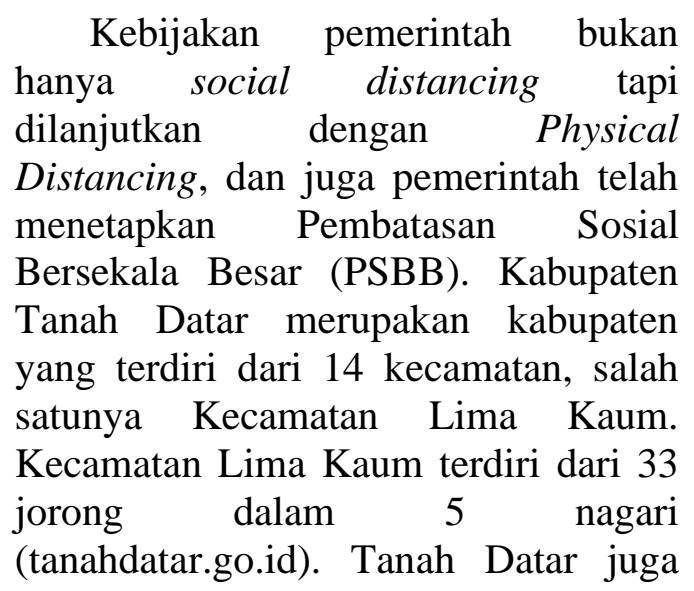

merupakan daerah yang saat ini berada dalam zona yang terdampak covid-19.

Kantor Kecamatan Lima Kaum merupakan instansi penyelenggara layanan publik yang membatasi layanan, menginisiasi layanan online bahkan sampai meniadakan pelayanan sementara, dengan bertambahnya pasien positif dengan angka yang tinggi, maka pemerintah memberlakukan Pembatasan Sosial Berskala Besar (PSBB). Pembatasan Sosial Berskala Besar (PSBB) adalah istilah kekarantinaan kesehatan di Indonesia yang didefinisikan sebagai pembatasan kegiatan tertentu penduduk dalam suatu wilayah yang diduga terinfeksi penyakit / terkontaminasi sedemikian rupa untuk mencegah kemungkinan penyebaran penyakit.

Saat diberlakukannya PSBB, Kantor Camat Lima Kaum memberlakukan sistem kerja satu hari masuk, satu hari libur dan juga melakukan Swab test untuk mengetahui apakah ada pegawai yang terinfeksi / terkontaminasi covid-19. Motivasi kerja yang diberikan oleh perusahaan terhadap karyawan bisa dalam berbentuk cara melakukan pendekatan kemanusiaan. Pendekatan kemanusiaan ini maksudnya dilakukan dengan memenuhi kebutuhan pegawai. Kebutuhan sangat penting dalam memotivasi pegawai apalagi di masa pandemi Covid-19.

\section{METODE:}

Jenis penelitian ini termasuk penelitian lapangan (field research) yaitu suatu penelitian yang dilakukan secara sistematis dengan mengangkat data yang ada dilapangan. Metode yang digunakan pada penelitian ini adalah 
menggunakan pendekatan penelitian kualitatif deskriptif. Menurut Sugiyono (2015: 15), metode penelitian kaulitatif adalah metode penelitian yang berlandaskan pada filsafat positivisme, digunakan untuk meneliti pada kondisi obyek yang alamiah (sebagai lawannya adalah eksperimen) dimana peneliti adalah instrument kunci, pengambilan sampel sumber data dilakukan secara purposive dan snowball.

Teknik pengumpulan dengan tringulasi (gabungan), analisis data bersifat induktif/kaulitatif dan hasil penelitian kualitatif lebih menekankan makna dari pada generalisasi.

Jadi melalui penelitian kualitatif ini penulis akan mengkaji berbagai aspek terkait dengan Strategi Komunikasi dalam Meningkatkan Motivasi Kerja Pegawai di Kantor Camat Lima Kaum di Masa Pandemi Covid-19.

Penulis melakukan penelitian ini di Kantor Camat Lima Kaum Kecamatan Lima Kaum Kabupaten Tanah Datar. Waktu penelitian dilaksanakan dari 8 Januari sampai 15 Januari 2021.

Peneltian kaulitatif, yang menjadi instrumen kunci penelelitian adalah peneliti sendiri. Peneliti mengungkap data secara lebih mendalam menggunakan pedoman wawancara dan panduan studi dokumen, camera handphone untuk merekam hasil wawancara.

Sumber data primer dari penelitian ini yaitu Kepala Camat, dan Staf-Staf Camat Lima Kaum. Sumber data sekunder dari penelitian ini yaitu melalui buku-buku tentang motivasi, website, jurnal ilmiah dan sumber relevan yang lainnya.
Teknik pengumpulan data yang digunakan dalam penelitian ini adalah dengan meggunakan observasi, wawancara dan dokumentasi.

Observasi adalah pengamatan yang dilakukan oleh panca indera manusia. Observasi sebagai teknik pengumpulan data biasanya dibagi menjadi dua partisipan dan non partisipan. Observasi dilakukan sesuai dengan jadwal jam kerja di Kantor Camat Lima Kaum, yakni jam 08.0014.00 WIB.

Wawancara adalah pertemuan antara dua orang untuk bertukar informasi dan ide melalui tanya jawab, sehingga dapat dikontruksikan makna dalam suatu topik tertentu Esterberg dalam (Sugiyono, 2015: 72). Dalam penelitian ini yang menjadi informan yaitu, Bapak camat dan staf-staf di kantor camat.

Dokumentasi menurut Sugiyono (2015: 329) adalah suatu cara yang digunakan untuk memperoleh data dan informasi dalam bentuk buku, arsip, dokumen, tulisan angka dan gambar yang berupa laporan serta keterangan yang dapat mendukung penelitian. Dokumentasi yang digunakan untuk mengumpulkan data kemudian, di reduksi, kemudian ditampilkan. Dokumentasi yang digunakan dalam memperoleh informasi dalam penelitian ini melalui yaitu Website Pemerintahan Kecamatan Lima Kaum.

Disini peneliti mengumpulkan, merangkum, memilih informasiinformasi yang pokok, memfokuskan pada informasi yang penting, dicari tema dan polanya. Dengan demikian data yang telah direduksikan memberikan gambaran yang lebih jelas terhadap Strategi Komunikasi Dalam 
Meningkatkan Motivasi Kerja Pegawai Di Kantor Camat Lima Kaum Di Masa Pandemic Covid-19.

Penyajian hasil penelitian ini dipaparkan deskriptif berdasarkan temuan di lapangan dengan bahasa khas dan pandangan emik informan agar mudah dipahami oleh pembaca. Melakukan interprestasi data yaitu menginterprestasikan apa yang telah diinterprestasi oleh informan terhadap masalah yang diteliti.

Pada tahap ini penelti melakukan interprestasi data sesuai dengan konteks permasalahan dari tujuan peneliti. Dari interprestasi yang dilakukan akan diperoleh kesimpulan dalam jawaban masalah penelitian.

Teknik tringulasi yang penulis gunakan adalah teknik tringulasi sumber, teknik dan waktu.

\section{HASIL DAN PEMBAHASAN}

Berdasarkan hasil wawancara dengan Kepala Camat Lima Kaum bahwa untuk meningkatkan motivasi karyawan di masa pandemi Covid-19, dengan melakukan monitoring dari segi kehadiran, output kerja, apakah tugas itu dikerjakan atau tidak, selesai dengan waktu yang ditetapkan atau tidak. Menurut RM bentuk tugas yang diberikan yaitu membuat SKP (Sasaran Kerja Pegawai) dengan program yang bernama Sistem Informasi Tambahan Penghasilan ASN (SITAMPAN), dalam menindak lanjuti Monitoring dan evaluasi setiap TUPOKSI di inpun ke dalam aplikasi, ada laporan kerja karyawan per-harinya, jadi pimpinan bisa menilai apakah karyawan bekerja sesuai dengan TUPOKSI dan juga pimpinan merevisi tugas yang dilaporkan oleh karyawan.
Untuk aliran komunikasi di dalam organisasi Kecamatan Lima Kaum, mengalir secara vertikal yang terdiri atas downward communication dan upward communication artinya bahwa komunikasi yang terjadi antara atasan dengan bawahan mengalir secara dua arah (two way communication) secara timbal balik, kerena di dalam komunikasi tersebut seorang pemimpin tidak hanya menginstruksikan kerja atau perintah kepada bawahannya namun disini pemimpin juga meminta saran dan juga pendapat atau ide-ide dalam melaksanakan tugas dan kewajibannya di dalam organiasi. Selain itu juga bawahan kepada atasannya akan memberikan laporan kerja, memberikan masukan, pendapat dan menyampaikan rencana dan program kerja dan lainnya yang menjadi tugas dan kewajibannya sesuai dengan TUPOKSI yang diberikan pimpinan.

Ditengah pandemi Covid-19 yang sedang dihadapi bersama saat ini, pastinya memberikan dampak yang signifikan terhadap kehidupan kita semua. Kehidupan New Normal yang saat ini kita jalankan pada organisasi akan menghadapi tantangan pasang surut motivasi kerja dari karyawannya oleh karenanya sangat penting menjaga motivasi kerja, agar pekerjaan yang dihasilkan bisa produktif, memunculkan inovasi-inovasi baru untuk kemajuan organisasi. Namun untuk ini semua diperlukan cara yang efektif bagaimana menanamkan semangat kerja dalam tim, mental seperti apa yang diperlukan untuk tetap produktif meskipun dalam situasi seperti saat ini, dalam meningkatkan motivasi kerja pegawai di masa pandemi Covid-19, Bapak Kepala 
Camat Lima Kaum selalu memberikan semangat kepada karyawan supaya tidak terpengaruh dengan situasi saat ini, karena semakin kurang bahagia saat melakukan pekerjaan maka semakin rendah produktivitas, dan seiring berjalannya waktu, motivasi kerja karyawan akan menurun.

AR menjelaskan dalam meningkatkan motivasi kerja pegawai di masa Covid-19, agar social distancing atau physical distancing tetap terlaksana, pimpinan menerapkan beberapa shift atau jadwal kerja yang mana dibagi menjadi dua kelompok, yaitu kelompok work from home (WFH) dan kelompok work from office (WFO). LS juga menjelaskan keuntungan dari pola kerja ini adalah operasional kantor yang berlaku prapandemi dapat cukup terjaga, karena karyawan secara bergiliran dapat beroperasi di kantor.

Seorang pemimpin diharapkan merespon secara cepat jika terdapat masalah dalam organisasi, WA menjelaskan jika suatu masalah cenderung dilalaikan penangganannya atau diabaikan masalah tetaplah masalah semakin diabaikan akan semakin bertambah masalah tersebut. SRD juga menjelaskan setiap terjadi persoalan di Kantor Camat Lima Kaum, pemimpin secara cepat merespon dan menangganinya, tetap diusahakan sebaik mungkin sesuai dengan persoalan yang dihadapi. Karena setiap persoalan berbeda penangganannya. HS mengatakan setiap persoalan yang dihadapi terkadang tidak bisa di selesaikan sendiri. Komunikasi yang terjadi di Kantor Camat Lima Kaum bersifat formal dan non formal. Komunikasi formal adalah proses komunikasi yang memanfaatkan saluran-saluran formal dalam organisasi. Biasanya terjadi ketika adanya rapat, seperti rapat antara Bapak Kepala Camat beserta karyawan di Kantor Camat Lima Kaum, dalam menindak lanjuti Covid19 yang mana salah satu karyawan di Kantor Camat Lima Kaum positif Covid-19.

Berdasarkan struktur organisasi di Kantor Camat Lima Kaum yang mana kasubag umum \& kepegawaian dan kasubag perencanaan \& keuangan setiap tugas atau informasi yang ada lansung di tindak lanjuti oleh sekretaris camat sedangkan bagian kasi lansung ditindak lanjuti oleh Bapak Camat. Sedangkan dalam bentuk non formal komunikasi antara Bapak Camat dan karyawan terjadi waktu istirahat hal ini dilakukan agar karyawan tidak canggung atau merasa tertekan dengan tugas yang diberikan. AD dan LS menjelaskan setiap karyawan mempunyai inisiatif yang berbeda dalam mengerjakan tugas yang diberikan berdasarkan uraian kerja masing-masing karyawan Karena karyawan akan menginpun data, jadi otomatis jika ada surat masuk dan surat masuk dan surat keluar maka karyawan akan lansung memprosesnya. Inisiatif adalah kemampuan untuk memutuskan dan melakukan sesuatu yang benar tanpa harus diberitahu, mampu menemukan apa yang seharusnya dikerjakan terhadap sesuatu yang ada di sekitar, berusaha untuk terus bergerak untuk melakukan beberapa hal walau keadaan terasa semakin sulit.

HS menjelaskan orang yang tidak percaya diri atau orang yang tidak puas dengan hasil kerjanya biasanya adalah orang yang gila akan penghormatan. Setiap karyawan yang melakukan tugas 
dengan tepat dan percaya diri pasti akan puas dengan apa yang dikerjakannya, tergantung karyawannya, apakah dia butuh dipuji atau tidak. HS juga menjelaskan karyawan di Kantor Camat Lima Kaum tidak ada yang haus akan pujian, RM juga menjelaskan karena keterbatasan karyawan apapun tugas yang diberikan akan dilakukannya sendiri tanpa meminta bantuan dari karyawan lain, karena karyawan lain juga memiliki kesibukannya dalam bekerja. Kalau karyawan bekerja dengan bagus tentu berhak menerima pujian dan reaward.

HS menyatakan Bapak Kepala Camat tidak memberikan reaward melainkan hanya memberikan pujian dan dorongan kepada karyawan agar terus meningkatkan kinerjanya, reward hanya diberikan bupati dengan istilah prestasi kinerja pegawai dengan melakukan perlombaan pegawai teladan. Tujuan pemberian penghargaan pegawai yaitu untuk mendorong dan memotivasi Pegawai Negeri Sipil meningkatkan aktivitas, kreativitas dan kinerja dalam pelaksanaan tugas. Menurut LS dengan memberikan pujian berupa semangat dan dorongan sudah membuat karyawan menjadi termotivasi untuk bekerja, dengan terlengkapinya sarana dan prasarana seperti komputer, printer, kertas Hvs dan mobilitas. SDR menyatakan sudah puas dengan hasil kerjanya sendiri. Kendaraan operasional di Kantor Camat Lima Kaum hanya untuk PNS yang menjabat / pejabat eselon, jadi PNS dan Non PNS yang tidak memiliki jabatan tidak diberi kendaraan, hanya menggunakan kendaraan pribadi. HS juga menjelaskan kendaraan Dinas Kantor Camat bisa dimanfaatkan untuk kepentingan perjalanan dinas, sesuai izin Bapak Kepala Camat.

Menurut AD, LS, dan WA yang didapatkan karyawan yaitu gaji, tunjangan penghasilan, tambahan penghasilan dan uang jalan. Gaji bersifat umum sesuai dengan pangkat dan golongan, tunjangan PNS tergantung dengan jabatannya semakin tinggi jabatannya semakin tinggi tunjangan yang di dapatkan (tunjangan antara kasi dan kasubag lebih tinggi kasi, sekcam lebih tinggi dari kasi, dan camat lebih tinggi dari sekcam). Sedangkan Non PNS tidak mendapatkan tunjangan, Non PNS hanya mendapatkan uang jalan dan tambahan dari iuran PNS, uang jalan yang diperoleh biasanya sekitar Rp. 110.000 sekali jalan di dalam Kabupaten, dalam Kecamatan Rp. 80.000, luar kabupaten Rp. 280.000 per-hari, tambahan penghasilan didapat berdasarkan kehadiran.

Bapak Kepala Camat menjelaskan pemberian sanksi di Kantor Camat Lima Kaum sesuai dengan aturan kedinasan sanksi berupa aturan jam kerja, jika ada yang terlambat, maka tambahan akan di potong sesuai dengan jumlah keterlambatan. Sanksi dalam kedisiplinan dalam bentuk teguran lisan dan teguran tertulis. RM menjelaskan kebutuhan akan rasa aman karyawan dimasa pandemi Covid-19 sudah terpenuhi, dengan meningkatkan antisipasi agar tidak tersebarnya Covid19, pemimpin memberikan kaca pembatas dibagian pelayanan, menyediakan westafel di luar kantor untuk karyawan dan masyarakat yang ingin mengunjungi kantor camat harus mencuci tangannya terlebih dahulu, adanya hand sanitizer, masker dan 
thermometer untuk mengukur suhu tubuh.

\section{KESIMPULAN}

Hasil penelitian mengenai "Strategi Komunikasi dalam Meningkatkan Motivasi Kerja Pegawai di Kantor Camat Lima Kaum di Masa Pandemi Covid-19" dapat disimpulkan bahwa.

Pertama: Strategi Komunikasi dalam Meningkatkan Motivasi Kerja Pegawai di Kantor Camat Lima Kaum di Masa Pandemi Covid-19. Strategi komunikasi dalam meningkatkan motivasi kerja pegawai di kantor camat Lima Kaum dengan melakukan monitoring dan evaluasi, melakukan pertemuan/ rapat evaluasi dengan karyawan minimal satu kali sebulan untuk mendengarkan dan mencari solusi dari kendala-kendala yang dihadapi oleh karyawan, menjalin hubungan yang baik dengan karyawan dan memberikan motivasi kepada karyawan untuk menjaga ketepatan waktu dalam bekerja, karena untuk memotivasi karyawan itu harus ada komunikasi yang efektif antara karyawan dan pimpinan.

Kedua: Faktor Internal dalam Meningkatkan Motivasi Kerja Pegawai di Kantor Camat Lima Kaum di Masa Pandemi Covid-19. Faktor internal dalam meningkatkan motivasi kerja pegawai di kantor camat Lima Kaum adalah adanya inisiatif karyawan dalam melaksanakan tugas yang diberikan oleh pimpinan dan adanya kepercayaan diri karyawan dalam melakukan tugasnya. Terlengkapinya kebutuhan operasional karyawan berupa komputer, kerta HVS, printer, dan kendaraan.
Ketiga: Faktor Eksternal dalam Meningkatkan Motivasi Kerja Pegawai di Kantor Camat Lima Kaum di Masa Pandemi Covid-19. Faktor eksternal dalam meningkatkan motivasi kerja pegawai di Kantor Camat Lima Kaum adalah tunjangan penghasilan, tambahan penghasilan dan uang jalan. Semakin tinggi jabatan, semakin tinggi tunjangan yang didapatkan.

\section{REFERENSI}

A.A Anwar Prabu Mangkunegara. 2006. Perencanaan dan Pengembangan Manajeman Sumber Daya Manusia. PT. Refika Aditama.

Ahmad Tanzeh. 2011. Metodologi Penelitian Praktis. Yogyakarta: Teras.

A.M, Sardiman. 2007. Interaksi dan Motivasi Belajar Mengajar. Jakarta: Raja Grafindo Persada.

Arikunto, S. 2006. Prosedur Penelitian Suatu Pendekatan Praktik. Ed Revisi VI. Jakarta: PT. Rineka Cipta

Cangara, Hafied. 2010. Pengantar Ilmu Komunikasi. Bandung: Rajawali Pers.

Cangara, Hafied. 2014. Perencanaan dan Strategi Komunikasi. Cetakan Kedua. Jakarta: PT Raja Grafido Persada.

Effendy, Onong Uchjana. 2013. Ilmu Komunikasi Teori dan Praktek. Bandung: PT Remaja Rosdakarya

Gomes, Fauston C. 2001. Manajeman Sumber Daya Manusia. Yogyakarta: Andi Offset.

Hasibuan, Malayu S.P. 2001. Manajemen Sumber Daya Manusia: Pengertian Dasar, 
Pengertian, dan Masalah. Jakarta: PT. Toko Gunung Agung.

Hasibuan, Malayu S.P. 2006. Manajeman Dasar, Pengertian, dan Masalah, Edisi Revisi.

Jakarta: Bumi Aksara.

Husein, Umar. 2013. Metode Penelitian untuk Skripsi dan Tesis. Jakarta: Rajawali.

Liliweri, Alo. 2014. Sosiologi \& Komunikasi Organisasi. Cet. 1. Jakarta: Bumi Aksara.

Maruli Raja T. Sitorus. 2020. Pengaruh Komunikasi Antarpribadi Pimpinan Tehadap Motivasi Kerja. Surabaya: Scopindo Media Pustaka. ISBN: 6236500665, 9786236500668.

Moleong, Lexy. 2006. Metodologi Penelitian Kualitatif. Bandung: PT. Remaja Rosdakarya

Mulyana, Deddy. 2013. Ilmu Komunikasi Suatu Pengantar. Bandung: PT Remaja Rosdakarya

Mulyana, D. 2012. Ilmu Komunikasi. Bandung: PT Remaja Rosdakarya

Novia, Windy. 2016. Kamus Ilmiah Populer. Jakarta: Pustaka Gama.

Pace, R Wayne and Don F. Faules. Dedy Mulyana (Editor). 2006. Komunikasi Organisasi, Strategi Meningkatkan Kinerja Perusahaan. Bandung: PT. Remaja Rosdakarya.

Purhantara, Wahyu. 2010. Metode Penelitian Kualitatif Untuk Bisnis. Yogyakarta: Graha Ilmu.

Purwanto, Ngalim. 2006. Psikologi Pendidikan. Bandung: PT Remaja Rosdakarya.

Robbins, P. Stephen. 2003. Perilaku Organisasi. Edisi Sembilan. Jilid 2. Edisi Bahasa Indonesia. Jakarta: PT Indeks Kelompok Gramedia
Robbins, P. Stephen. 2006. Perilaku Organisasi. Ed. 10. Diterjemahkan oleh: Drs. Benyamin Molan. Jakarta: Erlangga.

Ruliana, Poppy. 2014. Komunikasi Organisasi: Teori dan Studi Kasus. Ed. 1. Cet. 1. Jakarta: Rajawali Pers.

Siagian, Sodang P. 2006. Teori dan Kepemimpinan. Jakarta: Rineka Cipta.

Sugiyono. 2013. Metode Penelitiaan Pendidikan (Pendekatan Kuantitatif, Kualitatif dan $R \& D)$. Bandung: CV. Alfabeta.

Sugiyono. 2015. Metode Penelitiaan Pendidikan (Pendekatan Kuantitatif, Kualitatif dan $R \& D)$. Bandung: CV. Alfabeta.

Sugiyono. 2018. Metode Penelitian Kuantitatif, Kualitatif, dan $R \& D$. Bandung: Alfabeta.

Susanto, Yohanes. 2017. Peran Kepemimpinan dalam Pengelolaan Koperasi. Yogyakarta: Budi Utama

Wahjosumidjo. 2001. Kepemimpinan dan Motivasi. Jakarta: Ghalia Indonsesia.

Yulia, W. 2010. Andai Aku Jadi Penyiar. Yogyakarta: CV. Andi Offset.

\section{Jurnal:}

Aly, Yulianto, Makhub, dan Eko. 2018. Analisis Motivasi Kerja Guru di SMA Negeri 9 Semarang. Seminar Nasional Edusainstek. ISBN: 978-602-5614- 35-4.

Astuti, S. H., Dalinur, Darmawan C. 2019. Strategi Komunikasi Organisasi dalam Meningkatkan Etos Kerja Pegawai Kantor Camat Tungkal Jaya Kabupaten Musi Banyuasin. Jurnal Komunikasi Islam 3 (1): 23-25. 
Nabila, Agnes. 2018. Strategi Komunikasi dalam Interaksi dengan Mahasiswa Pertukaran Asing. Jurnal Gama Societa 2 (1): 9-16.

\begin{tabular}{lc} 
Peningkatan & \multicolumn{2}{c}{ Kinerja } \\
karyawan & Pada Perusahaan \\
Konstruksi. & BENEFIT Jurnal \\
Manajemen & dan Bisnis 4 (1): \\
52-68. & \multicolumn{2}{|}{}
\end{tabular}

Triemiaty, Maarif M. S., Affandi M. J., Website:

Pawenary. 2019. Strategi https://tanahdatar.go.id/ 